\title{
環状液体層内の磁気ベナール・マランゴニ対流*
}

\section{Magnetic Bénard-Marangoni Convection in an Annular Liquid Layer}

\author{
Toshio TAGAWA ${ }^{* 1}$ \\ ${ }^{* 1}$ Tokyo Metropolitan Univ. Dept. of Aerospace Engineering \\ Asahigaoka 6-6, Hino, Tokyo, 191-0065 Japan
}

The linear stability is studied for the Bénard-Marangoni convection in a diamagnetic liquid layer sustained by surface tension around a cylinder in the absence of gravitational force. A surface of the cylinder is kept at a constant temperature while a liquid surface is heated or cooled. An azimuthal magnetic field generated by an electric current through the central axis of the cylinder is considered. A combined convection takes place owing to the radial magnetic buoyancy force as well as the Marangoni effect acting at the liquid surface. It is shown that the convection of diamagnetic liquid can be enhanced or suppressed by the use of magnetic field.

Key Words : Diamagnetic Liquid, Bénard-Marangoni Convection, Linear Stability Analysis

\section{1. 緒言}

近年, 超伝導電磁石が商品化されたことから, 数テスラから 15 テスラ程度の強磁場が比較的容易に利用でき る状況にある．電磁流体力学の分野では，以前は導電性流体あるいは磁性流体の久が研究対象であったのに対 し, 最近では空気や水のような流体まで研究範囲が広がっており, それはこれまで無視されてきた磁気体積力 （単に磁気力，あるいは磁化力とも呼ばれる）に起因するものである。これまでの普通の電磁石が発生する磁 束密度を 0.1 から 1 テスラ程度とすると, 超伝導電磁石のそれは 10 から 100 倍のオーダーであり, 二乗に比例 する磁気エネルギーに換算すると千倍程度になる。これは鉄などの強磁性材料に比べて, 磁化率が非常に小さ いとされる空気や水においてさえ，強磁場下においては磁気体積力が重力に匹敵するほどに顕在化することを 意味する．この磁気力は，分子レベルで作用し，磁化率と磁場の 2 乗の勾配に比例する．単相で温度や濃度の 勾配がない状況下においては，この磁気力はポテンシャルを持つので，重力と類似している．その一方，磁化 率の正負に応じて, 引力と瓜力の両方が作用するという点で, 重力とは相違する部分もある. このように磁気 力は，重力と同様，保存力になりうる性質に加え，斥力も使えることから，温度や濃度に起因する自然対流や 二相流といった伝熱・流動の制御問題に関連して学術的に非常に興味深く, 今後の工学的応用が期待される.

空気は常磁性流体の代表的なものであり，磁化率が正であるため磁場から引力を受ける．空気は窒素や酸素 などから成る混合物であるが，窒素が普通の反磁性流体であるのに対し，酸素が例外的に大きな正の磁化率を 持つ常磁性流体であるため, 混合物としての空気は常磁性流体である. Wakayama ${ }^{(1)}$ にって発見された磁場中 における窒素ガスのジェット流は，空気と窒素の磁化率差および磁場勾配に起因して生じる現象である．水は 反磁性流体の代表的なものであり，その磁化率は負であり，微弱ながら磁場から反発される性質を持つ．空気 中の水滴に対して, 超伝導電磁石を用いて十数テスラ程度の強磁場の鉛直成分が上向きに小さくなって行くよ うに与えると，水滴は上向きの磁気反発力を受け，下向きの重力と釣り合い浮遊する．この時，周囲空気は下 向きの磁気引力を受けるので, その反作用として水滴には磁気浮力が働く. 雾囲気を常圧空気から高圧酸素な ぞに置き換えれば，この磁気浮力がより強くなるので，水滴はさらに浮上し易くなる(2).

\footnotetext{
* 原稿受付 2011 年 10 月 28 日

*1 正員, 首都大学東京（一191-0065 東京都日野市旭が丘 6-6）

E-mail: tagawa-toshio@sd.tmu.ac.jp
} 
流体の磁化率や密度の温度依存性に起因する現象の一例として, 磁気熱対流を挙げる. 一般に反磁性流体の 磁化率は温度依存しないが，常磁性流体のそれは温度に反比例することが，キュリーの法則として知られてい る.このことは, 空気のような常磁性流体が加熱されると磁化率が下がるため, 磁場に引き付けられる性質が 弱まり, 結果として相対的に高温部分の常磁性流体は磁場から反発されることになる. それは重力場における 浮力対流との対比で考えれば，加熱された流体が軽くなって上昇するのに対応している.

さて, 重力場における水平流体層の浮力対流の安定性は, Rayleigh-Bénard問題として良く知られ, Chandrasekar の著書 ${ }^{(3)}$ に詳述されている. Rayleigh の理論的研究に先立って, Bénardが鯨油を用いて行った実験では, 多数の 規則的な六角形の対流セル（Bénard セル）が観察された. その実験では，流体層は浅く上面が自由界面である 場合を扱っているので，今日では，浮力による影響よりはむしろ界面張力による影響（マランゴニ効果）がよ り重要な役割を果たしていることがわかっている．Pearson ${ }^{(4)}$ はマランゴニ効果のみで液体層内に対流が発生す ることを初めて理論解析により示した．それに先立ちBlock ${ }^{(5)}$ はマランゴニ対流を実験観察している． Nield ${ }^{(6)}$ は 浮力とマランゴニ効果が共存する場合の対流発生限界を初めて理論解析し, 両効果が重畳することによって, より不安定になりや寸くなることを示唆した. 日向野 $(7,8,9)$ は水平液体層におけるマランゴニ対流や浮力対流の 線形安定性, さらにはそれらの共存効果について, 熱的境界条件としてビオ数を用いて一般化し, 対流発生限 界式を与えている.

そのような対流発生限界に関する磁場を用いた研究として, Zebib ${ }^{(10)}$ は磁性流体を充填した同軸円筒容器内 の内外壁間に温度差をつけ，さらに中心軸の電流により発生する磁場勾配を与え，その結果として生じる対流 不安定性について理論解析を行い, 先に行われたOdenbach ${ }^{(11)}$ の落下塔による実験結果と比較し良好な一致を確 かめている．これら磁性流体の研究や筆者による空気を扱ったもの ${ }^{(12)} に$ 見られるように，無重力場で対流を発 生させるのに磁気力を用いた例は存在するが，それとは逆に無重力場でも発生するマランゴニ対流を磁場で抑 制する試みは見当たらない，そこで本研究では，自由界面を有する環状の反磁性液体層に生じるマランゴニ対 流に注目し，その制御方法としての磁場の有用性について線形安定性解析により考察寸る.

\section{2. 記 号}

$$
\begin{array}{ll}
a & : \text { 波数 }[1 / \mathrm{m}] \\
b & : \text { 磁束密度 }[\mathrm{T}] \\
B i & : \text { ビオ数 }[-] \\
d & : \text { 液体層厚さ }=r_{2}-r_{1}[\mathrm{~m}] \\
\boldsymbol{e}_{r} & : \text { 半径方向単位ベクトル }[-] \\
\boldsymbol{e}_{\theta} & : \text { 周方向単位ベクトル }[-] \\
f & : \text { 磁化力 }\left[\mathrm{N} / \mathrm{m}^{3}\right] \\
f_{r}: \text { 半径方向磁化力 }\left[\mathrm{N} / \mathrm{m}^{3}\right] \\
g \quad: \text { 重力加速度 }\left[\mathrm{m} / \mathrm{s}^{2}\right] \\
h \quad: \text { 熱伝達率 }\left[\mathrm{W} /\left(\mathrm{m}^{2} \cdot \mathrm{K}\right)\right] \\
\mathrm{i}: \text { 虚数単位 }[-] \\
i_{c}: \text { コイル電流 }[\mathrm{A}] \\
k: \text { 無次元波数 }[-] \\
m \quad: \text { 繰り返し数 }[-] \\
M a: \text { マランゴニ数 }[-] \\
M a^{*} \quad: \text { 修正マランゴニ数 }[-] \\
n \quad: \text { 周方向波数 }[-] \\
p \quad: \text { 圧力 }[\mathrm{Pa}] \\
P r \quad: \text { プラントル数 }[-] \\
q \quad: \text { 一様熱流束 }\left[\mathrm{W} / \mathrm{m}^{2}\right] \\
r: \text { 半径方向座標 }[\mathrm{m}] \\
\end{array}
$$

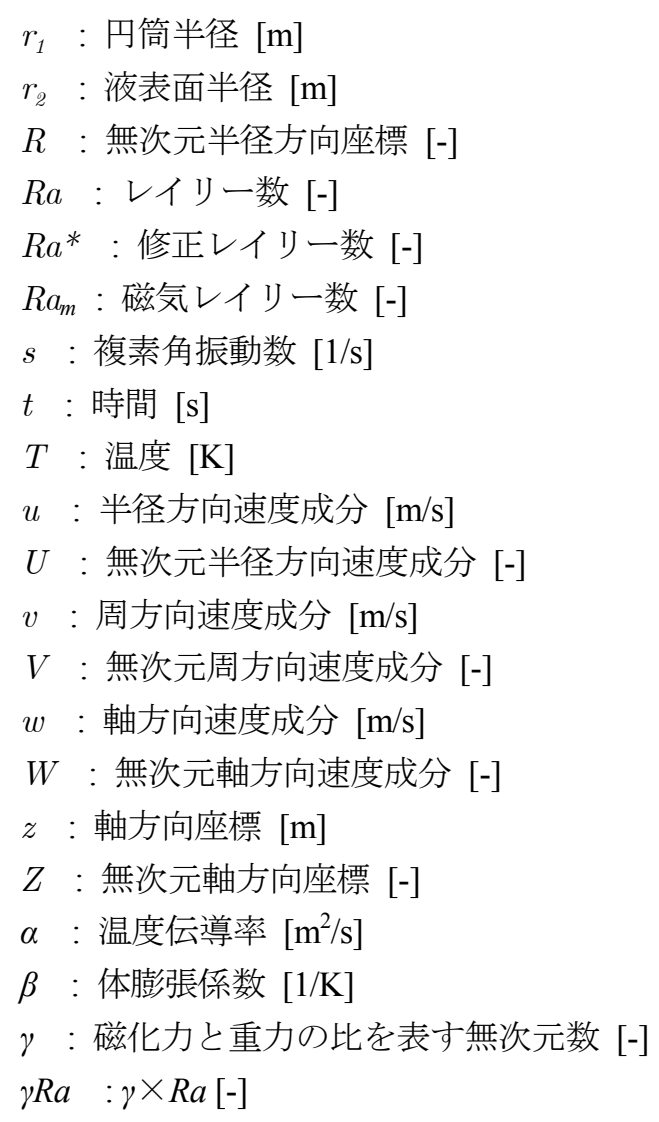




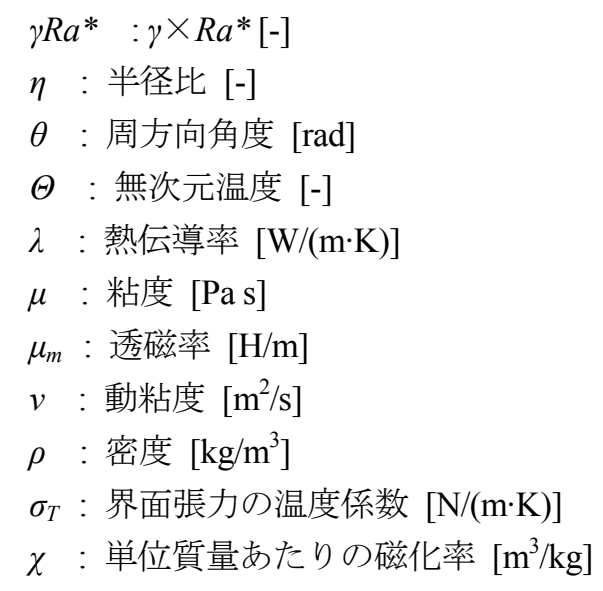

添え字：

$0 \quad$ : 温度 $T_{0}$ における物性值

1 : 円筒壁

2 : 液層表面

$m$ : 磁場

ss : 静止状態

$c$ : 臨界値

：変動量

：固有関数

\section{3. 支配方程式}

本研究で想定した解析モデルを図 1 に示寸，無重力場に置かれた円筒まわりの環状液体層を考え，中心軸上 の無限に長い直線コイルに一定值の電流が流れる，この電流が作る磁場は周方向成分のみを持ち，その強度は 軸からの距離に反比例する．液体としては主として反磁性流体である水を想定し， 円筒表面が一定温度に保持 され，外側の自由界面が気体と接している場合を考える。ここでは簡単化のために Rayleigh-Taylor の不安定性 の影響は無視できるものとし，磁場の有無に関わらず自由界面は界面張力で支えられ，真円柱形を保持し変形 はないものと仮定する. 半径方向の磁場勾配と温度勾配により生じる磁気熱的な効果と界面張力の温度依存性 の両方に依存して, 環状液体層の対流発生限界が決まる. 本研究ではコイルの電流值, 半径方向の温度勾配の 大きさと向き，代表長さとしての液体層の厚さを様々に変えて解析を行う.

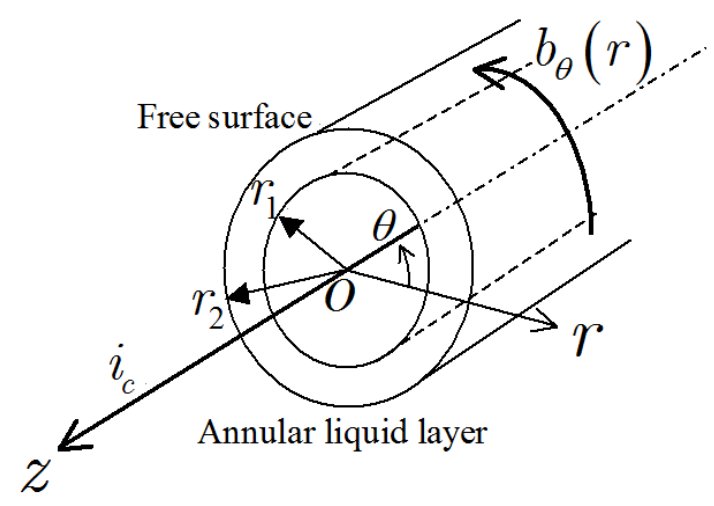

Fig. 1 Schematic of the problem considered. Instability within the annular liquid layer takes place owing to the azimuthal magnetic field as well as temperature dependence of surface tension.

以下, 解析に必要な基礎式を導出する. 本研究では, 液体層は非圧縮性のニュートン流体であると仮定する. 三次元円筒座標系における半径方向の運動方程式は, 次のように書ける.

$$
\begin{aligned}
& \rho\left(\frac{\partial u}{\partial t}+(\vec{u} \cdot \vec{\nabla}) u-\frac{v^{2}}{r}\right)=-\frac{\partial p}{\partial r}+\mu\left(\nabla^{2} u-\frac{u}{r^{2}}-\frac{2}{r^{2}} \frac{\partial v}{\partial \theta}\right)+f_{r} \\
& \text { ここに, 演算子はそれぞれ } \\
&(\vec{u} \cdot \vec{\nabla})=u \partial / \partial r+(v / r) \cdot \partial / \partial \theta+w \partial / \partial z, \quad \nabla^{2}=\partial^{2} / \partial r^{2}+(1 / r) \cdot \partial / \partial r+\left(1 / r^{2}\right) \cdot \partial^{2} / \partial \theta^{2}+\partial^{2} / \partial z^{2}
\end{aligned}
$$


とする. 次に, 無限直線コイルに流れる電流を $i_{c}$ とすれば, 発生する磁束密度分布はAmpèreの法則から求められ, 周方向成分だけを持つ.

$$
\vec{b}=\left(\mu_{m} i_{c} / 2 \pi r\right) \vec{e}_{\theta}
$$

ここで，常磁性あるいは反磁性流体に作用する磁化力は，流体の磁化率と磁場勾配に関係し，近似的に次式 で与えられる ${ }^{(13,14)}$.

$$
\vec{f} \cong \frac{\rho \chi}{2 \mu_{m}} \vec{\nabla}(\vec{b} \cdot \vec{b})=\frac{\rho \chi}{\mu_{m}}(\vec{b} \cdot \vec{\nabla}) \vec{b}
$$

第二項と第三項をつなぐ等号は，非導電性の媒質中で磁束密度の回転がゼロであること（Ampèreの法則）か ら容易にわかる. 近年の可視化実験と数値流体計算によって, この近似式の妥当性が確認されている ${ }^{(15)}$. 式(3), (4)から，次式のように磁化力は半径方向にのみ働くことがわかる.

$$
\vec{f}=-\frac{\rho \chi \mu_{m} i_{c}^{2}}{4 \pi^{2}} \frac{1}{r^{3}} \vec{e}_{r}
$$

次に重力場の熱対流にならって，Boussinesq近似を考える．水は反磁性体であるので，その単位質量あたりの 磁化率 $\chi$ は温度依存性がないものと見なされる，また，水は $4^{\circ} \mathrm{C}$ 付近で密度の最大值をとるが，本研究では水層 内の温度がどこでもすべて $4^{\circ} \mathrm{C}$ よりも高いものと仮定する．流体がある均一温度 $T_{0}$ にあるときは対流が発生しな いので，半径方向の運動方程式において磁化力と圧力勾配が釣り合って,

$$
0=-\frac{\partial p_{0}}{\partial r}-\frac{\rho_{0} \chi \mu_{m} i_{c}^{2}}{4 \pi^{2}} \frac{1}{r^{3}}
$$

を得る．ここで， $p_{0}$ は均一温度 $T_{0}$ にあるときの圧力場である．また $\rho_{0}$ は均一温度 $T_{0}$ にあるときの一定な密度を示 寸. なお，本来，気液界面が曲率を持っているので，界面の内外で圧力差を持っているが，その効果について は本論文では無視する. 式(1)と式(6)の差をとると次式を得る.

$$
\rho\left(\frac{\partial u}{\partial t}+(\vec{u} \cdot \vec{\nabla}) u-\frac{v^{2}}{r}\right)=-\frac{\partial\left(p-p_{0}\right)}{\partial r}+\mu\left(\nabla^{2} u-\frac{u}{r^{2}}-\frac{2}{r^{2}} \frac{\partial v}{\partial \theta}\right)-\left(\rho-\rho_{0}\right) \frac{\chi \mu_{m} i_{c}^{2}}{4 \pi^{2}} \frac{1}{r^{3}}
$$

体膨張係数の定義

$$
\beta=-(\partial \rho / \partial T) / \rho
$$

を考慮し, 密度の温度変化は近似的に次式で与えられる.

$$
\rho-\rho_{0} \cong(\partial \rho / \partial T)_{0}\left(T-T_{0}\right)=-\rho_{0} \beta\left(T-T_{0}\right)
$$

結局，水のような反磁性流体の場合，運動方程式の半径方向成分は，圧力差 $p$ - $p_{0}$ を $p$ と書き直し，以下のよう に書ける.

$$
\frac{\partial u}{\partial t}+(\vec{u} \cdot \vec{\nabla}) u-\frac{v^{2}}{r}=-\frac{1}{\rho_{0}} \frac{\partial p}{\partial r}+v\left(\nabla^{2} u-\frac{u}{r^{2}}-\frac{2}{r^{2}} \frac{\partial v}{\partial \theta}\right)+\chi \beta\left(T-T_{0}\right) \frac{\mu_{m} i_{c}^{2}}{4 \pi^{2}} \frac{1}{r^{3}}
$$

ここで, $v\left(=\mu / \rho_{0}\right)$ は動粘度である. 式(10)の右辺第三項は，重力場における浮力と同様，体積力である. 本

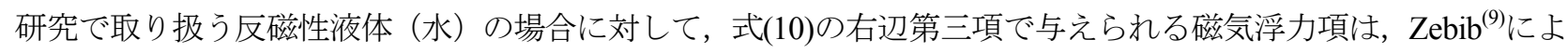


る磁性流体の理論解析で用いられた磁気力の項とは異なる．その論文においても中心軸上に沿う電流により発 生する周方向の磁場を考えているが, 結果として得られる磁気力の項は半径の 2 乗に反比例しており, 内外壁 間の磁場差および熱磁気係数（pyromagnetic coefficient）を用いて磁気レイリー数を定義している. 一方，本研究 では磁化力は半径の 3 乗に反比例しており, 中心軸の電流值や磁化率を用いて磁気レイリー数（後に式(54)で定 義）を定義する．その他の解析に必要な方程式は，それぞれ以下の通りである.

$$
\begin{aligned}
& \frac{\partial v}{\partial t}+(\vec{u} \cdot \vec{\nabla}) v+\frac{u v}{r}=-\frac{1}{\rho_{0}} \frac{1}{r} \frac{\partial p}{\partial \theta}+v\left(\nabla^{2} v-\frac{v}{r^{2}}+\frac{2}{r^{2}} \frac{\partial u}{\partial \theta}\right) \\
& \frac{\partial w}{\partial t}+(\vec{u} \cdot \vec{\nabla}) w=-\frac{1}{\rho_{0}} \frac{\partial p}{\partial z}+v\left(\nabla^{2} w\right) \\
& \frac{\partial u}{\partial r}+\frac{u}{r}+\frac{1}{r} \frac{\partial v}{\partial \theta}+\frac{\partial w}{\partial z}=0 \\
& \frac{\partial T}{\partial t}+(\vec{u} \cdot \vec{\nabla}) T=\alpha\left(\nabla^{2} T\right)
\end{aligned}
$$

式(11)，(12)は，それぞれ円周方向および軸方向の運動方程式である. 式(13)は連続の式である. 式(14)はエネ ルギー方程式である. 次に境界条件であるが，周囲気体の粘性効果は無視できるものと仮定すると，円筒壁 $(r=$ $\left.r_{1}\right)$ と自由界面 $\left(r=r_{2}\right)$ でそれぞれ以下のように書ける.

$$
\begin{cases}r=r_{1}: & u=0, \quad v=0, \quad w=0, \quad T=T_{1} \\ r=r_{2}: & u=0, \quad \mu r^{2} \partial(v / r) / \partial r=\sigma_{T} \partial T / \partial \theta, \quad \mu \partial w / \partial r=\sigma_{T} \partial T / \partial z, \quad \lambda \partial T / \partial r=h\left(T_{\infty}-T\right)\end{cases}
$$

式(15)において, 自由界面 $\left(r=r_{2}\right)$ における最初の式は, 界面は真円柱のまま変形しないという条件を意味し, 本研究ではそう仮定している. 二つ目の式は周方向の釣り合い式であり，三つ目の式は軸方向の釣り合い式で ある.ここに， $\sigma_{T}$ は界面張力の温度係数（温度に対寸る界面張力の変化率を表し，通常は負）を示す. 四つ目 の式は，自由界面での熱収支を意味する．ここに，hは熱伝達率を表し， $T_{\infty}$ は界面から十分離れた周囲気体の 温度を表す. 式(13)の両辺を $r$ で偏微分し, さらに式(15)のマランゴニ効果の条件式 (前述の二つ目, 三つ目の式) を考慮して，最終的に次式を得る.

$$
\frac{\partial}{\partial r}\left\{\frac{1}{r} \frac{\partial(r u)}{\partial r}\right\}=-\frac{\sigma_{T}}{\mu}\left(\frac{1}{r^{2}} \frac{\partial^{2} T}{\partial \theta^{2}}+\frac{\partial^{2} T}{\partial z^{2}}\right)
$$

\section{4. 線形安定性解析}

基本流は静止状態であり, 温度場は熱伝導状態である. 自由界面での温度は場所に依らず一定であり，それ を $T_{2}$ とすると, 次式で温度場が与えられる.

$$
T_{s s}(r)=\frac{T_{1} \ln \left(r / r_{2}\right)-T_{2} \ln \left(r / r_{1}\right)}{\ln \left(r_{1} / r_{2}\right)}
$$

このとき半径方向の運動方程式の釣り合いは静止状態の圧力 $p_{\mathrm{ss}}$ を用いて，次式で与えられる.

$$
0=-\frac{1}{\rho_{0}} \frac{\partial p_{s s}(r)}{\partial r}+\frac{\mu_{m} i_{c}^{2} \chi \beta}{4 \pi^{2}}\left(T_{s s}(r)-T_{0}\right) \frac{1}{r^{3}}
$$


次に, この基本状態からの変動分を

$$
u=u^{\prime}(r, \theta, z, t), \quad v=v^{\prime}(r, \theta, z, t), \quad w=w^{\prime}(r, \theta, z, t), \quad p=p_{s s}(r)+p^{\prime}(r, \theta, z, t), \quad T=T_{s s}(r)+T^{\prime}(r, \theta, z, t)
$$

と置き，式(10)-(14)をそれぞれ線形化し，以下の式を得る.

$$
\begin{aligned}
& \frac{\partial u^{\prime}}{\partial t}=-\frac{1}{\rho_{0}} \frac{\partial p^{\prime}}{\partial r}+v\left(\nabla^{2} u^{\prime}-\frac{u^{\prime}}{r^{2}}-\frac{2}{r^{2}} \frac{\partial v^{\prime}}{\partial \theta}\right)+\frac{\mu_{m} i_{c}^{2} \chi \beta}{4 \pi^{2}} \frac{T^{\prime}}{r^{3}} \\
& \frac{\partial v^{\prime}}{\partial t}=-\frac{1}{\rho_{0}} \frac{1}{r} \frac{\partial p^{\prime}}{\partial \theta}+v\left(\nabla^{2} v^{\prime}-\frac{v^{\prime}}{r^{2}}+\frac{2}{r^{2}} \frac{\partial u^{\prime}}{\partial \theta}\right) \\
& \frac{\partial w^{\prime}}{\partial t}=-\frac{1}{\rho_{0}} \frac{\partial p^{\prime}}{\partial z}+v\left(\nabla^{2} w^{\prime}\right) \\
& \frac{\partial u^{\prime}}{\partial r}+\frac{u^{\prime}}{r}+\frac{1}{r} \frac{\partial v^{\prime}}{\partial \theta}+\frac{\partial w^{\prime}}{\partial z}=0 \\
& \frac{\partial T^{\prime}}{\partial t}+u^{\prime} \frac{T_{1}-T_{2}}{\ln \left(r_{1} / r_{2}\right)} \frac{1}{r}=\alpha\left(\nabla^{2} T^{\prime}\right)
\end{aligned}
$$

さらに各変動量をノーマルモードの形で以下のように置く．

$$
\begin{cases}u^{\prime}(r, \theta, z, t)=\tilde{u}(r) \exp \{\mathrm{i}(n \theta+a z)+s t\}, & v^{\prime}(r, \theta, z, t)=\tilde{v}(r) \exp \{\mathrm{i}(n \theta+a z)+s t\} \\ w^{\prime}(r, \theta, z, t)=\tilde{w}(r) \exp \{\mathrm{i}(n \theta+a z)+s t\}, & p^{\prime}(r, \theta, z, t)=\tilde{p}(r) \exp \{\mathrm{i}(n \theta+a z)+s t\} \\ T^{\prime}(r, \theta, z, t)=\tilde{T}(r) \exp \{\mathrm{i}(n \theta+a z)+s t\} & \end{cases}
$$

ここで, $n$ は周方向波数であり整数, $a$ は軸方向波数であり実数, $s$ は角振動数であり一般には複素数である.

\section{$4 \cdot 1$ 軸対称擋乱}

周方向速度の変動波数 $n$ を無視し, 軸方向速度の変動波数 $a$ だけを考える. 式(20), (22), (23)から虚数単位, 軸 方向速度成分, および変動圧力を消去し整理すると次式を得る.

$$
\frac{v}{a^{2}}\left(\frac{d^{2}}{d r^{2}}+\frac{1}{r} \frac{d}{d r}-\frac{1}{r^{2}}-a^{2}-\frac{s}{v}\right)\left(\frac{d^{2}}{d r^{2}}+\frac{1}{r} \frac{d}{d r}-\frac{1}{r^{2}}-a^{2}\right) \tilde{u}=\frac{\mu_{m} i_{c}^{2} \chi \beta}{4 \pi^{2}} \frac{\tilde{T}}{r^{3}}
$$

一方，式(24)からは，ただちに次式を得る.

$$
\alpha\left(\frac{d^{2}}{d r^{2}}+\frac{1}{r} \frac{d}{d r}-a^{2}-\frac{s}{\alpha}\right) \tilde{T}=\frac{T_{1}-T_{2}}{\ln \left(r_{1} / r_{2}\right)} \frac{\tilde{u}}{r}
$$

境界条件は，円筒面では式(13), (15)を，一方で自由界面では式(15),(16)を考慮して次式を得る.

$$
\left\{\begin{array}{l}
r=r_{1}: \quad \tilde{u}=0, \quad d(r \tilde{u}) /(r d r)=0, \quad \tilde{T}=0 \\
r=r_{2}: \quad \tilde{u}=0, \quad\left(\frac{d^{2}}{d r^{2}}+\frac{1}{r} \frac{d}{d r}-\frac{1}{r^{2}}\right) \tilde{u}=a^{2} \frac{\sigma_{T}}{\mu} \tilde{T}, \quad d \tilde{T} / d r=-h \tilde{T} / \lambda
\end{array}\right.
$$


Chandrasekar ${ }^{(3)}$ によれば，回転も磁場も与えない水平流体層のレイリー・ベナール問題では，安定性の交換原 理が成立すること（sは実数であり，中立安定状態は $s=0$ によって特徴づけられること）が証明されている. 本 研究では, 磁化力とマランゴニ効果が共存し, その場合については安定性の交換原理の成立が証明されている わけではないが， $s=0$ を仮定し，さらに無次元化すると次式を得る.

$$
\begin{aligned}
& \left(D D_{*}-k^{2}\right)^{2} \tilde{U}=k^{2}\left(\gamma R a / 4 \pi^{2}\right)\left(\tilde{\Theta} / R^{3}\right) \\
& \left(D_{*} D-k^{2}\right) \tilde{\Theta}=\tilde{U} /(\ln \eta \cdot R)
\end{aligned}
$$

ここで, $D, D *$ は微分演算子を表し，それぞれ $D=d / d R, D_{*}=d / d R+1 / R$ である．無次元の境界条件は次式で与え られる。

$$
\left\{\begin{array}{l}
R=R_{1}: \quad \tilde{U}=0, \quad D \tilde{U}=0, \quad \tilde{\Theta}=0 \\
R=R_{2}: \quad \tilde{U}=0, \quad D_{*} D \tilde{U}=-k^{2} M a \cdot \tilde{\Theta}, \quad D \tilde{\Theta}=-B i \cdot \tilde{\Theta}
\end{array}\right.
$$

ここに, $k$ は軸方向の無次元波数, $\eta$ は内壁と自由界面の半径比である. また, $\gamma R a$ は無重力下の磁気熱対流で 現れる無次元数であり, 本研究における代表長さである水層厚 $d\left(=r_{2}-r_{1}\right)$ を用いて, 次式で定義する.

$$
\gamma R a=\frac{\chi \mu_{m} i_{c}^{2} \beta\left(T_{1}-T_{2}\right)}{\alpha \nu}=\underbrace{\frac{\chi \mu_{m} i_{c}^{2}}{g d^{3}}}_{\gamma<0} \underbrace{\frac{g \beta\left(T_{1}-T_{2}\right) d^{3}}{\alpha v}}_{R a}
$$

最後の項の前半 $(\gamma)$ は, 磁化力と重力の比を表す無次元数 (反磁性体では負) であり, 後半はレイリー数 $(R a)$ である. 重力場ではこれら 2 つ無次元数が独立に現れるが, 無重力場ではこれらの積の形 $(\gamma R a)$ でのみ現れ, それが磁場印加により負の值（磁化率 $\chi か ゙$ 負であるので $T_{1}>T_{2}$ ）をとるとき安定な系となる. また本問題では仮 に, 円筒内壁面が高温で自由界面が低温の系とすると, 界面張力の温度係数 $\sigma_{T}$ が負の時に不安定となる. マラン ゴニ数は次式のように，正の值で不安定となるように次式で定義する.

$$
M a=-\frac{\sigma_{T}\left(T_{1}-T_{2}\right) d}{\mu \alpha}
$$

無次元の半径 $R$, 軸方向波数 $k$, およびビオ数 $B i$ については, 以下の通り定義される.

$$
R=r / d, \quad k=a d, \quad B i=h d / \lambda
$$

式(29), (30)を境界条件である式(31)のもとに解けば，層が不安定となり対流が発生する限界が得られる.

\section{$4 \cdot 2$ 周方向変動擋乱}

軸方向速度の変動波数 $k$ を無視し, 周方向速度の変動波数 $n$ だけを考える. 先と同様にして, 式(20), (21), (23) から, 虚数単位, 周方向速度成分, および変動圧力を消去する. さらに $s=0$ とすると, 結局, 次の無次元式を 連立して解く固有值問題に帰着される.

$$
\left(D^{4}+\frac{6}{R} D^{3}+\frac{5-2 n^{2}}{R^{2}} D^{2}-\frac{2 n^{2}+1}{R^{3}} D+\frac{\left(n^{2}-1\right)^{2}}{R^{4}}\right) \tilde{U}=n^{2} \frac{\gamma R a}{4 \pi^{2}} \frac{\tilde{\Theta}}{R^{5}}
$$




$$
\left(D_{*} D-n^{2} / R^{2}\right) \tilde{\Theta}=\tilde{U} /(\ln \eta \cdot R)
$$

無次元の境界条件は，以下の通りである.

$$
\begin{cases}R=R_{1}: & \tilde{U}=0, \quad D \tilde{U}=0, \quad \tilde{\Theta}=0 \\ R=R_{2}: & \tilde{U}=0, \quad D * D \tilde{U}=-n^{2} M a \cdot \tilde{\Theta} / R^{2}, \quad D \tilde{\Theta}=-B i \cdot \tilde{\Theta}\end{cases}
$$

\section{$4 \cdot 3$ 三次元擋乱}

二次元の擋乱を与える場合には，運動方程式の各成分から圧力および虚数単位を消去して 4 階の常微分方程 式を導出した，一方で，円筒座標系において三次元擋乱（ $k, n$ はともに非ゼロ）を与える場合には，それを実 行するのは面倒に思われるため, 下記の連立常微分方程式を実部と虚部に分け, スタッガード格子上で中心差 分により離散化し，直接的に差分計算を行う。

$$
\begin{aligned}
& 0=-D \tilde{P}+\left(D D_{*}-n^{2} / R^{2}-k^{2}\right) \tilde{U}-2 \mathrm{i} n \tilde{V} / R^{2}+(\gamma R a \cdot \tilde{\Theta}) /\left(4 \pi^{2} R^{3}\right) \\
& 0=-\mathrm{i} n \tilde{P} / R+\left(D D_{*}-n^{2} / R^{2}-k^{2}\right) \tilde{V}+2 \mathrm{i} n \tilde{U} / R^{2} \\
& 0=-\mathrm{i} k \tilde{P}+\left(D_{*} D-n^{2} / R^{2}-k^{2}\right) \tilde{W} \\
& D_{*} \tilde{U}+\mathrm{i} n \tilde{V} / R+\mathrm{i} k \tilde{W}=0 \\
& 0=\left(D_{*} D-n^{2} / R^{2}-k^{2}\right) \tilde{\Theta}-\tilde{U} /(\ln \eta \cdot R)
\end{aligned}
$$

無次元の境界条件は以下の通りであり, 圧力の境界条件は不要である.

$$
\begin{cases}R=R_{1}: & \tilde{U}=0, \quad \tilde{V}=0, \quad \tilde{W}=0, \quad \tilde{\Theta}=0 \\ R=R_{2}: & \tilde{U}=0, \quad \tilde{V}=R D \tilde{V}+\mathrm{i} n M a \cdot \tilde{\Theta}, \quad D \tilde{W}=-\mathrm{i} k M a \cdot \tilde{\Theta}, \quad D \tilde{\Theta}=-B i \cdot \tilde{\Theta}\end{cases}
$$

\section{$4 \cdot 4$ 計算手法および結果}

ある磁場強度を与えたとき, 臨界マランゴニ数を求める方法について, 周方向擋乱解析の場合の式(35), (36), (37)を例に取り示す. 式(35)は 4 階の微分方程式であるので,

$$
D^{2} \tilde{U}=\tilde{F}
$$

と置き, 最高次が 2 階の微分方程式に階数を落とし, 同時に仮想時間項を導入する.

$$
\frac{\partial \tilde{F}}{\partial \tau}=\frac{\partial^{2} \tilde{F}}{\partial R^{2}}+\frac{6}{R} \frac{\partial \tilde{F}}{\partial R}+\frac{5-2 n^{2}}{R^{2}} \tilde{F}-\frac{2 n^{2}+1}{R^{3}} \frac{\partial \tilde{U}}{\partial R}+\frac{\left(n^{2}-1\right)^{2}}{R^{4}} \tilde{U}-n^{2} \frac{\gamma R a}{4 \pi^{2}} \frac{\tilde{\Theta}}{R^{5}}
$$

式(36), (44)にも仮想時間項を導入する.

$$
\frac{\partial \tilde{\Theta}}{\partial \tau}=\frac{\partial^{2} \tilde{\Theta}}{\partial R^{2}}+\frac{1}{R} \frac{\partial \tilde{\Theta}}{\partial R}-\frac{n^{2}}{R^{2}} \tilde{\Theta}-\frac{\tilde{U}}{\ln \eta \cdot R}
$$




$$
\frac{\partial \tilde{U}}{\partial \tau}=\frac{\partial^{2} \tilde{U}}{\partial R^{2}}-\tilde{F}
$$

基本的には，式(45), (46),(47)の連立方程式を四次精度中心差分で離散化し時間発展的に解いた. 例えば，臨界

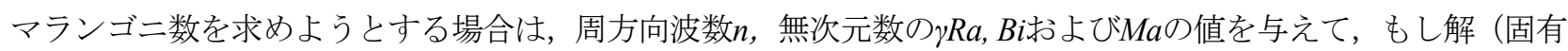
関数) が時間的に増幅も減衰もしないなら, そのときがその $n, \gamma R a, B i$ に対応寸る中立のMaとなる. 本研究では, 次式で定める $R_{2}$ （自由界面）における值 $D_{M a}$ がゼロに近づくようにニュートン法を用いて，与えた $n, \gamma R a, B i$ に対 応する中立のマランゴニ数Maを修正しながら求めた.

$$
{ }^{m+1} M a={ }^{m} M a-c_{0} \frac{{ }^{m} D_{M a}}{\left(n^{2} / R_{2}^{2}\right) \tilde{\Theta}\left(R_{2}\right)}, \quad{ }^{m} D_{M a}=\tilde{F}\left(R_{2}\right)+\frac{S}{R_{2}}+\frac{n^{2}}{{R_{2}}^{2}}{ }^{m} M a \cdot \tilde{\Theta}\left(R_{2}\right)
$$

ここで, 左上付添字 $m$ は反復回数を表し， $c_{0}$ は定数である．そのような操作を様々な整数值 $n$ に対して行い中 立マランゴニ数を求め, その中で最小のものを臨界マランゴニ数とする. また, そのときの $n$ を臨界波数とする. 式(48)の後半のものは式(37)で与えられる境界条件（マランゴニ効果）に対応寸るものだが，Sについての説明は 後述する. 一方でマランゴニ数を固定し, $\gamma R a$ の臨界值を求める場合は, 式(45)から考えて, 次式により $\Delta \tilde{F}$ の変 化が無くなる様に求めた. $R *$ は $R_{1}$ と $R_{2}$ の間で任意に定めた值である.

$$
{ }^{m+1}(\gamma R a)={ }^{m}(\gamma R a)-c_{1} \frac{m\left(\Delta \tilde{F}\left(R_{*}\right)\right)}{-n^{2} \cdot \tilde{\Theta}\left(R_{*}\right) /\left(4 \pi^{2} R_{*}^{5}\right)} \Delta \tau
$$

図 2 に各固有関数の一例（半径比が $2 / 3$, つまり $R_{1}=2, R_{2}=3$ の計算結果）を示寸．ただし，縦軸の值それ自 身は意味を持たず，4つの曲線は視覚的にわかりやすくするために，それぞれ拡大率を変えて表示（Uは $R=2.5$

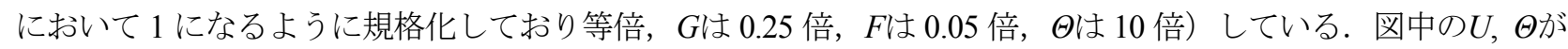
それぞれ半径方向の速度, 温度を示す. 文字の上にある記号「〜」の表示は省略している. $\tilde{F}$ は式(44)の示す通 り $\tilde{U}$ の 2 階微分である. また, $\tilde{G}$ は $\tilde{U}$ の 1 階微分である. 次に, 境界条件の与え方の説明に移る. 式(37)では, 両境界上でU の微分值である $\tilde{F}$ は両境界において非ゼロの值をとっていることから判るように, 式(45)を解く際に陽に境界条 件を与えることができない. そこで, 固体壁一自由界面の本問題であっても $\tilde{G}$ の定積分值は常にゼロであり, かつ $\tilde{G}$ の壁面上 $\left(R=R_{1}\right)$ の值がゼロであることを利用する. つまり，数式では以下のように表される.

$$
\int_{R_{1}}^{R_{2}} \tilde{G}(R) d R=\tilde{U}\left(R_{2}\right)-\tilde{U}\left(R_{1}\right)=0 \quad \text { and } \quad \tilde{G}\left(R_{1}\right)=0
$$

その結果， $\tilde{F}$ の定積分值は， $\tilde{G}$ の自由界面上 $\left(R=R_{2}\right)$ の値となる.

$$
\int_{R_{1}}^{R_{2}} \tilde{F}(R) d R=\tilde{G}\left(R_{2}\right)
$$

本数值解析では, 式(50)の $\tilde{G}$ の定積分值（ゼロとなるべき）を $D$ と置き，また，式(51)の $\tilde{F}$ の定積分値を $S$ と する. 実際の解析では, $\tilde{F}$ の自由界面における境界值は, 式(37)の中のマランゴニ効果を示寸条件から求める.

$$
\tilde{F}\left(R_{2}\right)=-\tilde{G}\left(R_{2}\right) / R_{2}-\left(n^{2} / R_{2}{ }^{2}\right) M a \cdot \tilde{\Theta}\left(R_{2}\right)
$$

一方， $\tilde{F}$ の円筒壁における境界值は，ニュートン法により次式を用いて， $D=0$ を満たすように求めた.

$$
{ }^{m+1} \tilde{F}\left(R_{1}\right)={ }^{m} \tilde{F}\left(R_{1}\right)-c_{2} \cdot{ }^{m} D
$$


ここで，左上付き添え字 $m$ は繰り返し回数を表す． $c_{2}$ は定数である.Dは計算の開始直後はゼロからずれてい るが，収束するにつれてゼロに近づいていく．なお本計算では，格子数を 101 とし，Simpson法により $\tilde{F}, \tilde{G}$ の数 值積分を行った。

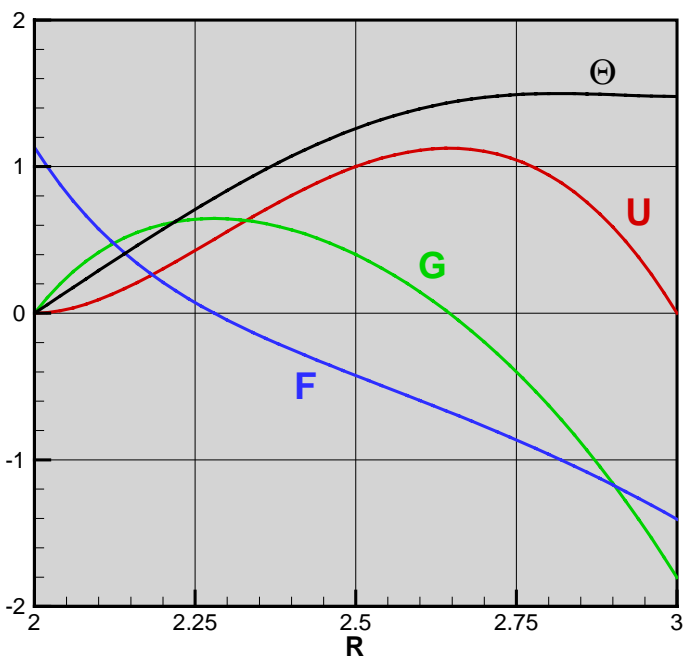

Fig. 2 An example of each eigenfunction for $\eta=2 / 3, M a=$ 74.30, $B i \rightarrow 0$ and $\gamma R a=0$ (azimuthal disturbance)

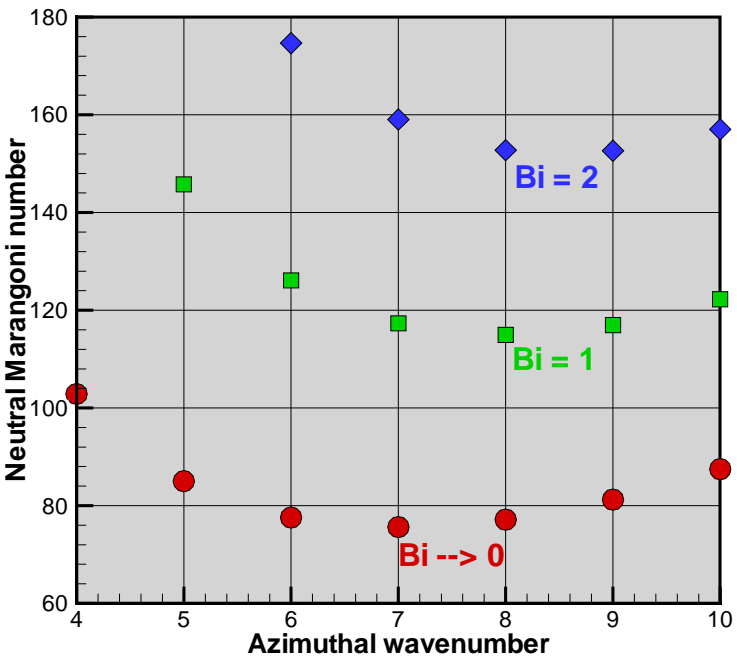

Fig. 3 The relationship between the wavenumber and the neutral values of $M a$ for $\eta=3 / 4$ and $\gamma R a=0$

図 3 は，一例として，二次元極座標解析（周方向変動擋乱を与えた場合）における半径比が $3 / 4$ の時の周方向 波数 $n$ と中立のマランゴニ数の関係を示す. 磁場が印加されない場合であるので，界面張力の温度係数を負とす ると，円筒壁が高温で自由界面が冷却される場合に対流が発生することを意味する．本解析によると，Bi $\rightarrow 0$ では波数が 7 のとき臨界值 $M a_{c}=76.52$ をとる. ビオ数が大きくなるにしたがって, 臨界マランゴニ数は大きく なり，それに対応する臨界波数も大きくなる傾向が見て取れる．表 1 は， $\gamma R a=0$ （磁場無し）での臨界マラン ゴニ数のまとめを示す. 軸対称擋乱 (表中ではAxisymmetric disturbanceと表記) および周方向変動擋乱 (Azimuthal

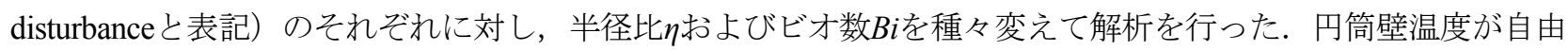
界面の温度よりも高温である場合, $M a>0$ （温度係数が負の必要がある）で不安定となり臨界值を超えると対流 が発生する．ビオ数がゼロの場合，半径比が同じ解析条件では，二次元極座標解析で得られる臨界值が軸対称 解析のそれよりも常に小さくなるという結果が得られ，その傾向は半径比が小さいほど顕著である．ところが ビオ数が $10 ， 100$ と大きくなっていくと，両解析による臨界值に違いはほとんど見られない．軸対称解析にお

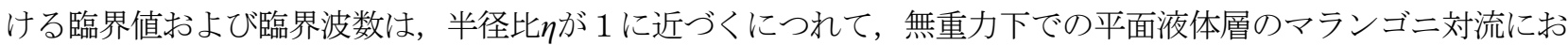
ける臨界值 ${ }^{(6,7)}$ (表中で $\eta=1$ と示す) に近づいていくのがわかる.

Table 1 Critical values obtained by the linear stability analyses for $\gamma R a=0$

\begin{tabular}{|c|c|c|c|c|c|c|c|c|c|c|c|c|}
\hline \multirow{2}{*}{} & \multicolumn{9}{|c|}{ Axisymmetric disturbance } & \multicolumn{4}{c|}{ Azimuthal disturbance } \\
\cline { 2 - 16 } & \multicolumn{3}{|c|}{$B i \rightarrow 0$} & \multicolumn{2}{|c|}{$B i=10$} & \multicolumn{2}{c|}{$B i=100$} & \multicolumn{2}{c|}{$B i \rightarrow 0$} & \multicolumn{2}{|c|}{$B i=10$} & \multicolumn{2}{c|}{$B i=100$} \\
\hline$\eta$ & $k_{\mathrm{c}}$ & $M a_{\mathrm{c}}$ & $k_{\mathrm{c}}$ & $M a_{\mathrm{c}}$ & $k_{\mathrm{c}}$ & $M a_{\mathrm{c}}$ & $n_{\mathrm{c}}$ & $M a_{\mathrm{c}}$ & $n_{\mathrm{c}}$ & $M a_{\mathrm{c}}$ & $n_{\mathrm{c}}$ & $M a_{\mathrm{c}}$ \\
\hline $1 / 2$ & 1.843 & 81.48 & 2.677 & 485.6 & 2.899 & 3970 & 3 & 71.37 & 4 & 471.6 & 5 & 3979 \\
\hline $2 / 3$ & 1.902 & 79.76 & 2.701 & 451.0 & 2.926 & 3658 & 5 & 74.30 & 7 & 444.5 & 8 & 3675 \\
\hline $3 / 4$ & 1.928 & 79.41 & 2.712 & 438.7 & 2.939 & 3544 & 7 & 75.62 & 10 & 435.2 & 11 & 3561 \\
\hline $5 / 6$ & 1.951 & 79.30 & 2.722 & 428.6 & 2.952 & 3450 & 11 & 76.95 & 15 & 426.8 & 17 & 3463 \\
\hline $9 / 10$ & 1.969 & 79.34 & 2.731 & 421.8 & 2.962 & 3385 & 19 & 78.01 & 26 & 420.9 & 28 & 3393 \\
\hline $19 / 20$ & 1.981 & 79.44 & 2.737 & 417.3 & 2.969 & 3342 & 39 & 78.80 & 54 & 416.9 & 58 & 3346 \\
\hline 1 & 1.993 & 79.61 & 2.743 & 413.4 & 2.976 & 3304 & & & - & & \\
\hline
\end{tabular}


続いて，マランゴニ数をゼロとしたときの臨界值を表 2 に示寸。この場合は，流れの駆動力は水の密度の温 度依存性に基づく磁気浮力によるものであり, 円筒壁の温度が自由界面の温度より低温でなければ対流は発生 しない．軸対称解析では，半径比 $\eta$ が 1 に近づくと，重力場における平面液体層の臨界值に近づいていくのが見 て取れる.なお，磁気レイリー数に換算すると，例えば $\eta=0.95$ では, $\gamma R a=1.987 \times 10^{8}$ は $R a_{m}=678.8$ に相当し， これはビオ数をゼロとした時に得られる平面の場合の臨界レイリ一数 ${ }^{(6,8)}$ (表中で $\eta=1, R a_{\mathrm{c}}=669.0, k_{\mathrm{c}}=2.086$ ) に極めて近いことがわかる. ここで用いた磁気レイリー数は, 相加平均半径を用いて次式で定義した ${ }^{(12)}$.

$$
R a_{m}=\frac{\gamma R a}{4 \pi^{2}}\left(\frac{R_{1}+R_{2}}{2}\right)^{-3}
$$

Table 2 Critical values obtained by the linear stability analyses for $M a=0$ and $B i \rightarrow 0$

\begin{tabular}{|c|c|c|c|c|c|c|}
\hline & \multicolumn{3}{|c|}{ Axisymmetric disturbance } & \multicolumn{3}{c|}{ Azimuthal disturbance } \\
\hline$\eta$ & $k_{\mathrm{c}}$ & $\gamma R a_{\mathrm{c}}$ & $R a_{\mathrm{mc}}$ & $n_{\mathrm{c}}$ & $\gamma R a_{\mathrm{c}}$ & $R a_{\mathrm{mc}}$ \\
\hline $1 / 2$ & 2.049 & $1.020 \times 10^{5}$ & 765.5 & 3 & $8.003 \times 10^{4}$ & 600.6 \\
\hline $2 / 3$ & 2.058 & $4.536 \times 10^{5}$ & 735.4 & 5 & $3.979 \times 10^{5}$ & 645.1 \\
\hline $3 / 4$ & 2.065 & $1.217 \times 10^{6}$ & 719.0 & 7 & $1.113 \times 10^{6}$ & 657.6 \\
\hline $5 / 6$ & 2.071 & $4.610 \times 10^{6}$ & 701.9 & 11 & $4.369 \times 10^{6}$ & 665.2 \\
\hline $9 / 10$ & 2.077 & $2.331 \times 10^{7}$ & 688.7 & 20 & $2.259 \times 10^{7}$ & 667.4 \\
\hline $19 / 20$ & 2.081 & $1.987 \times 10^{8}$ & 678.8 & 41 & $1.958 \times 10^{8}$ & 668.9 \\
\hline 1 & 2.086 & - & 669.0 & & - & \\
\hline
\end{tabular}

さらに, 水の界面張力の温度係数は負のままとし, 円筒壁を一定温度に保ち, 自由界面を加熱する場合を考 える. 表 3 には，マランゴニ数を- 80 に固定した場合に対する $\gamma R a$ の臨界值を示す．この場合，マランゴニ効果 は対流を妨げるので, 対流発生にはそれに逆らってより強い磁場が必要になる. 表 2 と表 3 の比較からすると, およそ 2 倍程度の磁場を印加することにより対流が発生する. なお, 表 3 に示される各臨界波数は両解析とも 表 1 や表 2 よりも若干大きい傾向が見て取れる.

Table 3 Critical values obtained by the linear stability analyses for $M a=-80$ and $B i \rightarrow 0$

\begin{tabular}{|c|c|c|c|c|c|c|}
\hline & \multicolumn{3}{|c|}{ Axisymmetric disturbance } & \multicolumn{3}{c|}{ Azimuthal disturbance } \\
\hline$\eta$ & $k_{\mathrm{c}}$ & $\gamma R a_{\mathrm{c}}$ & $R a_{\mathrm{mc}}$ & $n_{\mathrm{c}}$ & $\gamma R a_{\mathrm{c}}$ & $R a_{\mathrm{mc}}$ \\
\hline $1 / 2$ & 2.592 & $1.747 \times 10^{5}$ & 1311 & 4 & $1.524 \times 10^{5}$ & 1144 \\
\hline $2 / 3$ & 2.509 & $8.042 \times 10^{5}$ & 1304 & 6 & $7.430 \times 10^{5}$ & 1205 \\
\hline $3 / 4$ & 2.477 & $2.181 \times 10^{6}$ & 1289 & 8 & $2.069 \times 10^{6}$ & 1222 \\
\hline $5 / 6$ & 2.449 & $8.336 \times 10^{6}$ & 1269 & 13 & $8.066 \times 10^{6}$ & 1228 \\
\hline $9 / 10$ & 2.430 & $4.236 \times 10^{7}$ & 1251 & 23 & $4.158 \times 10^{7}$ & 1228 \\
\hline $19 / 20$ & 2.417 & $3.622 \times 10^{8}$ & 1237 & 47 & $3.590 \times 10^{8}$ & 1226 \\
\hline
\end{tabular}

図 4 は, 半径比が 0.75 の場合に対して, 二次元極座標解析で得られたまとめであり, 縦軸に $R a_{m}$, 横軸に $M a$ を取ったときの対流発生限界線図を表す，丸印近傍の整数は臨界值をとったときの波数を示す．縦軸が 0 (磁場 なし）のときの臨界マランゴニ数は表 1 で示した通り, 約 $76(B i \rightarrow 0)$ である. 横軸が 0 (マランゴニ効果なし) のときの臨界磁気レイリー数は表 2 で示した通り, 約 $658(B i \rightarrow 0)$ である. 本研究では, 液体層として水（表 面張力の温度係数が負，体膨張係数が正，および磁化率が負）を想定しているので，この図において意味をな すのは, $M a>0$ かつ $R a_{m}<0$ の領域 1 ， あるいは $M a<0$ かつ $R a_{m}>0$ の領域 2 だけである (右図参照). まず 領域 1 では, 内壁を加熱し自由界面を冷却する場合に対応し，マランゴニ対流を磁場で抑制することに対応す 


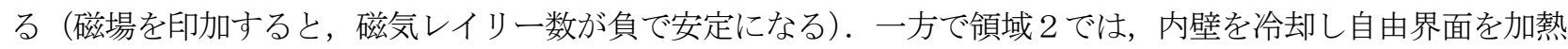
する場合に相当し，マランゴニ効果で安定な液体層を磁場印加により不安定にし，対流が発生することに相当 する（磁場を印加すると，磁気レイリー数が正で不安定になる）。 ちなみに, $M a>0$ かつ $R a_{m}>0$ の領域 3 は, 磁化率が正，つまり常磁性液体の場合に相当寸る領域であり，内壁が加熱で自由界面が冷却される場合では， マランゴニ効果と磁場効果がともに層を不安定にさせる. ビオ数が 100 では, 臨界磁気レイリー数のマランゴ 二数依存性は小さく, ほぼ 1100 程度の值をとり, 図中のマランゴニ数の範囲内では臨界波数に変化は見られな い. ビオ数が無限大に漸近すると, 自由界面の温度は均一となりマランゴニ効果は消滅することからも妥当な 結果と言える.
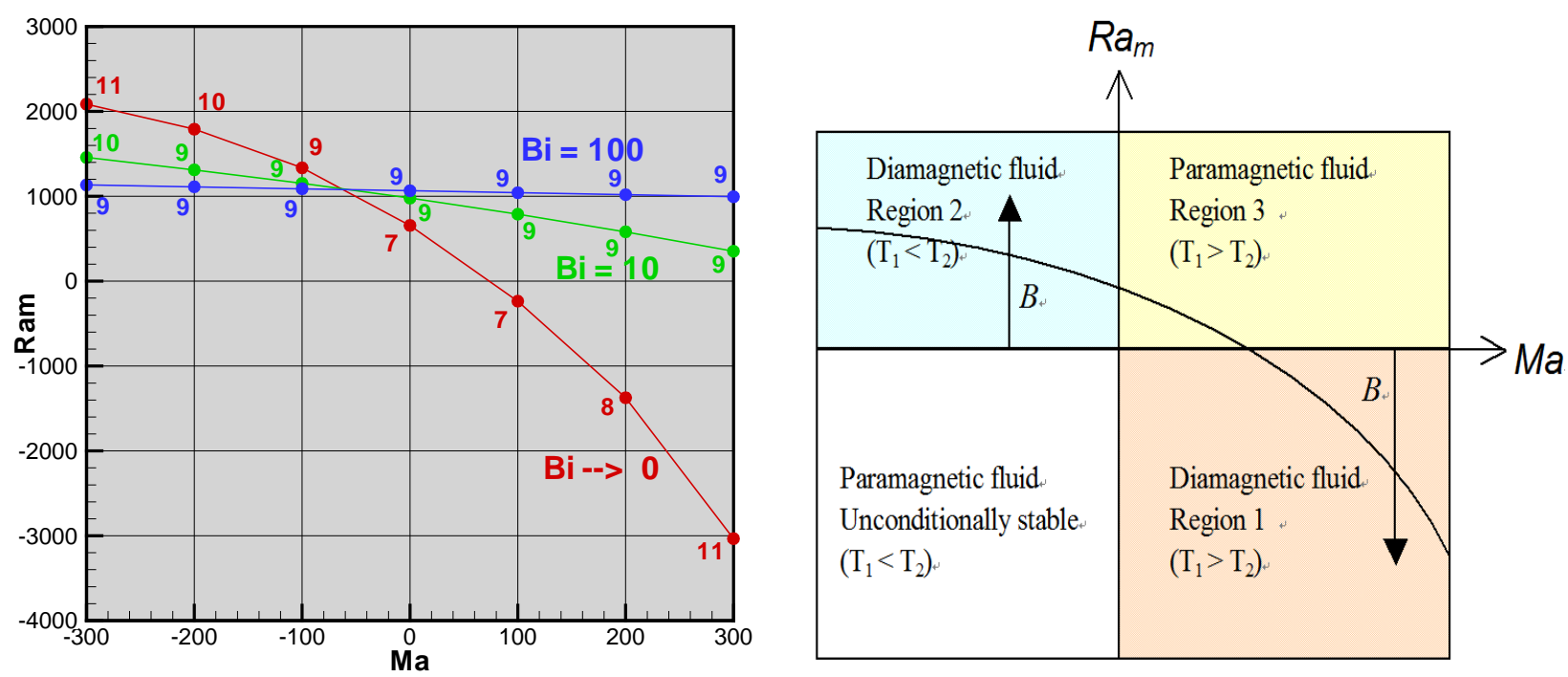

Fig. 4 The critical magnetic Rayleigh number as a function of the Marangoni number at $\eta=3 / 4$. The numbers indicate the critical azimuthal wavenumber. The right one indicates the stability diagram in which points below a curve represent stable states.

\section{$4 \cdot 5$ 三次元定常流の可能性}

式(38) - (43)で与えられる定常三次元擋乱の固有值問題を解いた結果について少し述べる. 一例として, 表 2 （マランゴニ効果を無視し磁場のみ印加）で半径比が 0.75 の場合について，周方向波数 $n$ と軸方向波数 $k$ の両方 を変化させて計算を行った結果を図 5 に示す. 縦軸は $\gamma R a$, 横軸は軸方向波数 $k$, 図中の数字が周方向波数 $n$ を示 す. $n$ が 7 よりも小さいときは， $k$ の極小值を持つことが示されたが，それらのいずれも最小值をとることは無 かった，従って，臨界值は周方向擋乱 $(n=7, k=0)$ のときに，臨界值 $1.113 \times 10^{6}$ をることが示された.

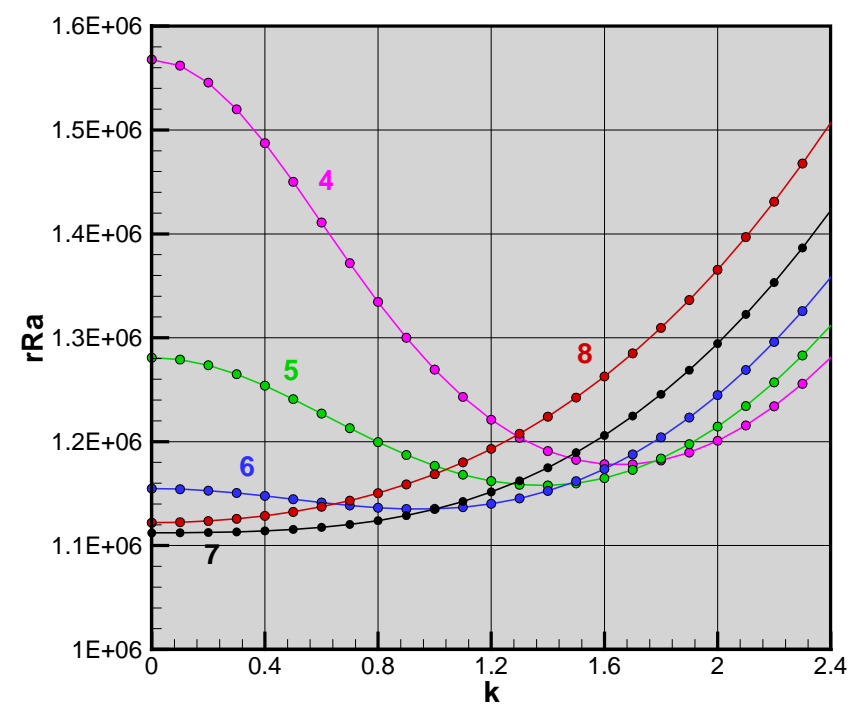

Fig. 5 The effect of three-dimensional disturbance on neutral values for $\eta=3 / 4, M a=0$ and $B i \rightarrow 0$ 


\section{5. 数值解析}

\section{$5 \cdot 1$ 無次元方程式と解析方法}

線形安定性解析で得られた結果の妥当性の検証と非線形効果の両方を検討寸ることを目的として, 差分法に よる数值解析にも少し触れる. 対流発生臨界值を超え, 温度分布が熱伝導状態からずれてくる場合, 熱伝達率 $h$ が局所的に変化する. このような場合, 自由界面における温度境界条件の設定に対して, 式(34)で与えられるビ 才数を用いることに疑問が生じる. ここでは, 前節の $B i \rightarrow 0$ の結果と比較するために, 自由界面を一様熱流束

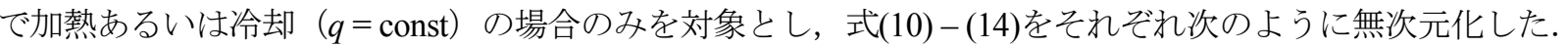

$$
\begin{aligned}
& \frac{\partial U}{\partial \tau}+(\vec{U} \cdot \vec{\nabla}) U-\frac{V^{2}}{R}=-\frac{\partial P}{\partial R}+\operatorname{Pr}\left(\nabla^{2} U-\frac{U}{R^{2}}-\frac{2}{R^{2}} \frac{\partial V}{\partial \theta}\right)-\frac{\gamma R a^{*} \cdot \operatorname{Pr}}{4 \pi^{2}} \frac{\Theta}{R^{3}} \\
& \frac{\partial V}{\partial \tau}+(\vec{U} \cdot \vec{\nabla}) V+\frac{U V}{R}=-\frac{1}{R} \frac{\partial P}{\partial \theta}+\operatorname{Pr}\left(\nabla^{2} V-\frac{V}{R^{2}}+\frac{2}{R^{2}} \frac{\partial U}{\partial \theta}\right) \\
& \frac{\partial W}{\partial \tau}+(\vec{U} \cdot \vec{\nabla}) W=-\frac{\partial P}{\partial Z}+\operatorname{Pr}\left(\nabla^{2} W\right) \\
& \frac{\partial U}{\partial R}+\frac{U}{R}+\frac{1}{R} \frac{\partial V}{\partial \theta}+\frac{\partial W}{\partial Z}=0 \\
& \frac{\partial \Theta}{\partial \tau}+(\vec{U} \cdot \vec{\nabla}) \Theta=\nabla^{2} \Theta
\end{aligned}
$$

境界条件は，円筒壁面上では等温の滑り無しとし，自由界面では一様熱流束で加熱あるいは冷却し，さらに マランゴニ効果を加味する．自由界面で加熱の場合は以下のように表される.

$$
\left\{\begin{array}{l}
R=R_{1}: \quad U=0, \quad V=0, \quad W=0, \quad \Theta=0 \\
R=R_{2}: \quad U=0, \quad R \frac{\partial}{\partial R}\left(\frac{V}{R}\right)=-\frac{M a^{*}}{R} \frac{\partial \Theta}{\partial \theta}, \quad \frac{\partial W}{\partial R}=-M a^{*} \frac{\partial \Theta}{\partial Z}, \quad \frac{\partial \Theta}{\partial R}=1
\end{array}\right.
$$

ここに, $M a^{*}$ は修正マランゴニ数を表し，伝熱面が一定温度ではなく熱流束が一定の場合に用いられる. $\gamma R a^{*}$ は, 磁化力と重力の比を表寸無次元数 $\gamma$ に修正レイリー数 $R a^{*}$ 垂じた形になっている. 無次元数は $M a^{*}, \gamma R a^{*}$ に加えて, 運動方程式中に非線形項が含まれるためプラントル数 $P r$ も現れる. 無次元の変数および無次元数は 以下のように定義される.

$$
\begin{aligned}
& \tau=\frac{t}{d^{2} / \alpha}, R=\frac{r}{d}, Z=\frac{z}{d}, U=\frac{u}{\alpha / d}, V=\frac{v}{\alpha / d}, W=\frac{w}{\alpha / d}, P=\frac{p}{\rho_{0} \alpha^{2} / d^{2}}, \Theta=\frac{T-T_{1}}{-q d / \lambda}, \\
& \operatorname{Pr}=\frac{v}{\alpha}, \quad \gamma R a^{*}=\frac{\chi \mu_{m} i_{c}^{2} \beta q d}{\alpha v \lambda}, M a^{*}=-\frac{\sigma_{T} q d^{2}}{\alpha \mu \lambda}, \eta=\frac{r_{1}}{r_{2}}=\frac{r_{1}}{r_{1}+d}, A=\frac{z_{0}}{d}, R_{1}=\frac{r_{1}}{d}, R_{2}=\frac{r_{2}}{d}=R_{1}+1
\end{aligned}
$$

上記の支配方程式ならびに境界条件は，円筒座標系にて差分法を用いて時間発展的に解いた．格子分割には 等間隔のスタッガードメッシュを採用し，圧力の解法には，連続の式を満足させる HSMAC (Highly Simplified Marker And Cell) 法を用い，また移流項には三次精度の上流差分法の一つである UTOPIA (Uniformly Third-Order Polynomial Interpolation Algorithm) スキームを用いた。

\section{$5 \cdot 2$ 計算結果}


臨界值を与えると推測される二次元極座標での計算結果のみに限定する. 図 6 には，プラントル数が 6 ，半 径比が $3 / 4$ である場合の速度場（矢印による表示）および温度場（高温部が赤，低温部が青に対応）の定常状態 を示す．まず，(a) では表 1 の結果と比較するために，磁場なしで修正マランゴニ数は 70 としているが，これ は円筒壁が高温で自由界面が冷却される場合に対応する. 本計算により得られた周方向波数は 7 であり，線形 安定性解析で得られる波数 7 に一致する. また, (b) には表 2 と比較するために, マランゴニ効果が無く, $\gamma R a^{*}$ $=1.0 \times 10^{6}$ の場合を示す．この場合は円筒壁が低温で自由界面が加熱されなければ対流は発生しない，得られた 周方向波数は 7 であり，線形安定性解析で得られる波数に一致している.さらに，(c) には表 3 に対応した場合 を示す. 流速が(a), (b) と比べて若干大きいので, 速度ベクトルの矢印の大きさは(a), (b)の 1/3 倍で描画している. 円筒壁が低温で自由界面が加熱されている系であるので，マランゴニ効果により液体層は安定であるが，それ を補うだけのより強い磁場印加により層内が不安定になり対流発生する. 自由界面では安定化を助長するマラ ンゴニ効果により速度が幾分抑制されている様子がわかる，なお，本計算では(a), (b), (c)のいずれの場合におい ても, 線形安定性解析で得られる臨界值より若干低い臨界值においても対流が発生したが，波数に関してはほ ぼ一致を示した。

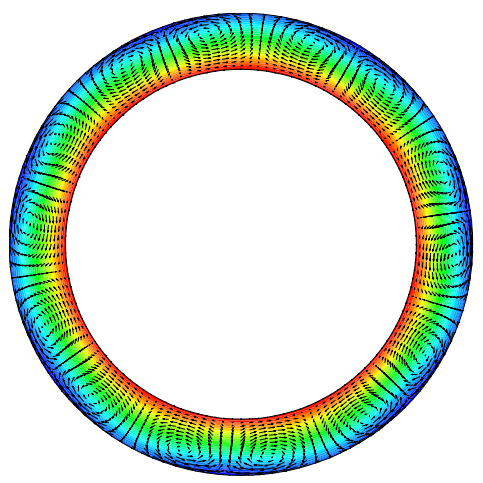

(a) $M a^{*}=70, \quad \gamma R a^{*}=0$,

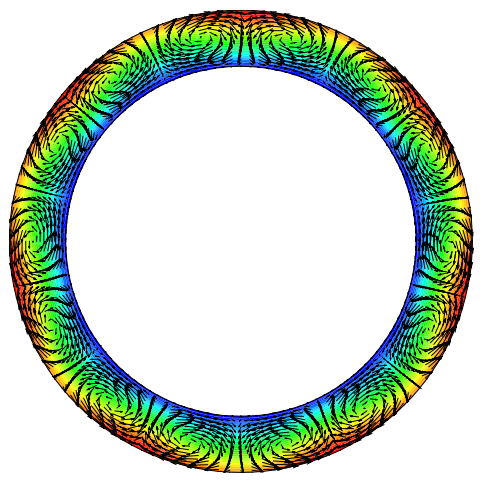

(b) $M a^{*}=0, \quad \gamma R a^{*}=1.0 \times 10^{6}$,

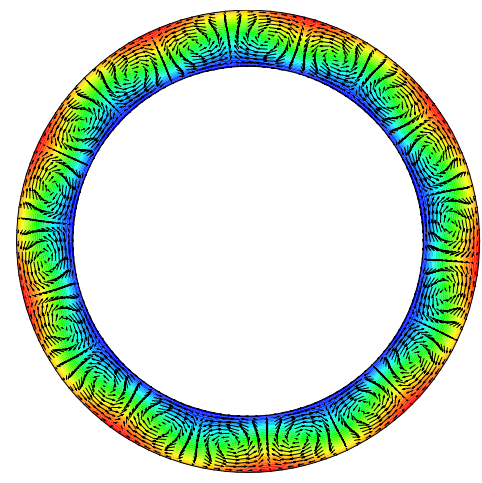

(c) $M a^{*}=-80, \quad \gamma R a^{*}=2.0 \times 10^{6}$

Fig. 6 Velocity vectors and temperature field obtained for each steady state at $\eta=3 / 4$ and $\operatorname{Pr}=6$

図 7 は表 1 にほぼ対応する計算をしたものであり，半径方向の速度成分の時間成長率を示す．縦軸を対数ス ケールでとると，図に示されるように非線形効果が現れるまでは直線的に成長していく．この傾きがゼロにな るときの $M a^{*}$ が臨界修正マランゴニ数ということになるが，その值は 65 よりは大きく 70 よりは小さいことが わかる．なお， $M a^{*}=65$ の計算では，ゼロから開始する場合に加えて，流れが発達した $M a^{*}=70$ の速度が発達 した結果を初期条件として継続計算させた場合も実施したが，いずれの場合も速度は減衰する結果となった.

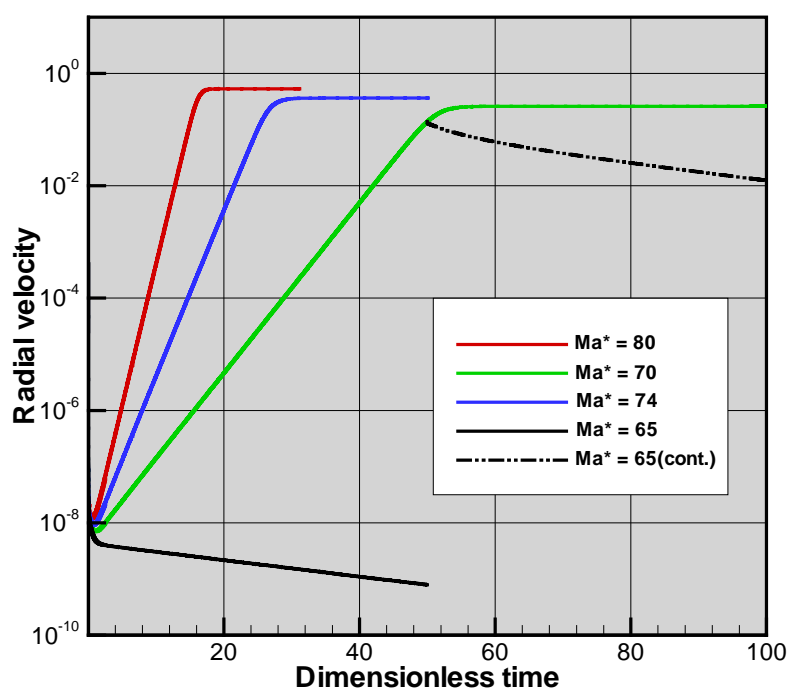

Fig. 7 Growth rate of the velocity for several modified Marangoni numbers at $\eta=3 / 4, \gamma R a^{*}=0$ and $\operatorname{Pr}=6$ 


\section{6. 考 察}

\section{$6 \cdot 1$ 線形解と非線形解の比較}

前節で行った非線形数值計算では，対流発生の臨界值を超えた領域での流れの計算が可能であるが，表 1 , 2，3のいずれの場合においても，波数に関してはほぼ一致したものの，線形解析で得られた臨界值よりもや や低い值に関わらず有限の対流が発生した．非線形計算では，パラメータにMa* や $\gamma R a^{*}$ を用いているが，これ はそれぞれ $M a$ や $\gamma R a$ にヌセルト数を掛けたものと解釈されるので，対流発生限界付近では，この違いは問題と ならないはずである. 線形解析では，す心゙て 4 次精度の中心差分で離散化して格子点数 101 で解いているのに 対し，非線形解析では，上流差分を用いていること，また半径方向の格子点数が 32 であることを考慮すると， 非線形解の方に精度の不十分さが多く残されていると考えられる. 最後に，有限の対流であっても線形解析の 予測通りの波数が生成されたことを考えると，本問題においては，各フーリエ成分間の相互作用がそれほど強 くなく，擋乱が成長しても高調波の生成が顕著には起きなかったものと考えられる.

\section{$6 \cdot 2$ 有次元換算例}

水の物性值を用いて, 中心軸上のコイル電流值や円筒壁面上における磁束密度の概略值を求めるものとする. ここで, 水の物性值は, 密度 $\rho=1000 \mathrm{~kg} / \mathrm{m}^{3}$, 磁化率 $\chi=-9.1 \times 10^{-9} \mathrm{~m}^{3} / \mathrm{kg}$, 透磁率 $\mu_{\mathrm{m}}=4 \pi \times 10^{-7} \mathrm{H} / \mathrm{m}$, 温度伝導率 $\alpha=$ $1.6 \times 10^{-7} \mathrm{~m}^{2} / \mathrm{s}$, 動粘度 $v=9.6 \times 10^{-7} \mathrm{~m}^{2} / \mathrm{s}$, 界面張力の温度係数 $\sigma_{\mathrm{T}}=-1.5 \times 10^{-4} \mathrm{~N} /(\mathrm{m} \cdot \mathrm{K})$, 体膨張係数 $\beta=2.1 \times 10^{-4} 1 / \mathrm{K}$ とする. 現実的な一例として, $\left.\eta=0.75, B i=100, M a=4000 （ T_{1}>T_{2}\right)$ のベナール・マランゴニ対流（表 1 の結 果によれば, $M a=3561$ 以上で対流が発生）を磁場印加により流れを抑制するものとする. 本解析によれば, $\gamma R a$ $=-3.224 \times 10^{5} \quad\left(R a_{\mathrm{m}}=-190\right)$ に相当する磁場を印加するときが対流発生限界である．まず，温度差を $1^{\circ} \mathrm{C}$ と仮定 して，マランゴニ数の定義式(33)から代表長さ $d$ を求める.

$$
d=r_{2}-r_{1}=-\{\mu \alpha M a\} /\left\{\sigma_{T}\left(T_{1}-T_{2}\right)\right\} \cong 4.10 \times 10^{-3}[\mathrm{~m}]
$$

次に，式(32)からコイル電流值は

$$
i_{c}=\sqrt{\{(\gamma R a) \cdot \alpha v\} /\left\{\chi \mu_{m} \beta\left(T_{1}-T_{2}\right)\right\}} \cong 1.44 \times 10^{5}[\mathrm{~A}]
$$

となる. したがって, 内壁 $\left(r_{1}=12.3 \mathrm{~mm}\right)$ における磁束密度は次式のようになる.

$$
\left.b_{\theta}\right|_{1}=\left(\mu_{m} i_{c}\right) /\left(2 \pi r_{1}\right) \cong 2.34[\mathrm{~T}]
$$

円管内断面が全てコイルであると仮定すると，その電流密度值は約 $300 \mathrm{~A} / \mathrm{mm}^{2}$ であり，現在実用化されてい るニオブチタン合金などの超伝導材料を用いれば十分に発生可能な数值である. 温度差が半分 $\left(0.5^{\circ} \mathrm{C}\right)$ になれ ば，それぞれ代表長さは 2 倍，コイル電流值は約 1.4 倍，磁束密度は約 0.7 倍となる. この例に見るように， $T_{1}>$ $T_{2}$ であれば，ビオ数がある程度大きく，かつ発生するべナール・マランゴニ対流が臨界值を少し超える程度であ れば, 磁場印加により対流を抑制できる可能性が十分にある.一方で, $T_{1}<T_{2}$ のように温度条件を逆転させれば, マランゴニ効果で安定な層であっても磁場印加により対流を発生させることは原理的には可能である. 工学的 応用として, 例えば，円管外表面における膜状凝縮の熱伝達促進が考えられるが，反磁性体の磁化率は小さい ので, 非常に大きな磁束密度（10 テスラ程度以上）が必要となる.もし仮に, 反磁性で磁化率の絶対值の大き な冷媒が存在しそれを用いるなら, 膜状凝縮の伝熱促進の可能性も考えられる.

\section{7. 結 語}

円管まわりの環状水層の磁気ベナール・マランゴニ対流について, 線形安定性解析ならびに非線形数值解析 を行い，次の知見を得た。 
1. 磁場を印加しない場合，円筒壁を冷却し自由界面を加熱すると，界面張力の温度係数が負の場合は安 定である，逆に対流を発生させようとすると，円筒壁を加熱し自由界面を冷却する必要がある。半径比が 1 に近づくとき，環状液体層の臨界マランゴニ数は平面液体層のそれに漸近する.

2. 定常三次元擋乱を与える安定解析も一部行ったが，臨界值をとるのは軸方向の波数がゼロ（二次元の 周方向撹乱）の場合という結果が得られた.

3. 水は反磁性体 (磁化率が負) であるので，体膨張係数が正となる温度領域 $\left(4^{\circ} \mathrm{C}\right.$ 上上）において，円筒 壁を冷却し自由界面を加熱する場合, 磁場印加により生じる磁気浮力のため不安定となり, 対流が発生す る可能性が示唆された．ただし，その臨界值である磁気レイリー数が 1100 程度というのは，水の磁化率 の絶対值が小さいことを考慮すると，円筒壁上で 10 テスラ程度以上の磁束密度が必要である，逆に，円 筒壁を加熱し自由界面を冷却すると, 磁場印加により生じる磁気浮力はベナール・マランゴニ対流を安定 化させる作用（重力場における密度成層状態に類似）を持つ. 特に，ビオ数がある程度大きくかつ磁場な しの臨界マランゴ二数を少し超えた程度であれば，対流抑制できる可能性は高いと考えられる。

4. 常磁性液体である場合，もしくは反磁性液体であっても体膨張係数あるいは表面張力の温度係数のど ちらかが通常とは逆の傾向を示す場合，マランゴ二効果と磁場効果が相乗して，系を不安定化（内壁が高 温で自由界面が低温）あるいは安定化（内壁が低温で自由界面が高温）させる。この場合は，Nield が理 論解析した重力場での水平液体層のベナール・マランゴニ対流と類似性がある.

\section{文献}

(1) Wakayama, N.I., "Behavior of gas flow under gradient magnetic fields", Journal of Applied Physics, Vol. 69, (1990), pp. 2734-2736.

(2) Ikezoe, Y., Hirota, N., Nakagawa, J. and Kitazawa, K., "Making water levitate”, Nature, Vol. 393, (1998), pp.749-750.

(3) Chandrasekar, S., Hydrodynamic and Hydromagnetic Stability, Dover, (1961).

(4) Pearson, J. R. A., “On convection cell induced by surface tension”, Journal of Fluid Mechanics, Vol. 4, (1958), pp. 489-500.

(5) Block, M. J., "Surface tension as the cause of Benard cells and surface deformation in a liquid film", Nature, Vol. 178, (1956), pp. 650-651.

(6) Nield, D. A., "Surface tension and buoyancy effects in cellular convection", Journal of Fluid Mechanics, Vol. 19, (1964), pp. 341-352.

（7）日向野三雄, “液体層の熱的不安定性（第一報, 界面張力による場合)”, 日本機械学会論文集 B 編, Vol. 47, No. 413 (1981), pp. 105 - 112.

（8）日向野三雄, “液体層の熱的不安定性 (第二報, 浮力による場合)”, 日本機械学会論文集 B 編, Vol. 47, No. 413 (1981), pp. $113-120$.

（9）日向野三雄，“液体層の熱的不安定性（第三報，浮力と界面張力の共存する場合）”，日本機械学会論文集 B 編, Vol. 47, No. 420 (1981), pp. 1571 - 1577.

(10) Zebib, A., “Thermal convection in a magnetic fluid”, Journal of Fluid Mechanics, Vol. 321, (1996), pp. 121-136.

(11) Odenbach, S., "Drop tower experiments on thermomagnetic convection", Microgravity Science and Technology, Vol. 6, No. 3, (1993), pp. 161-163.

(12) 田川俊夫, “同軸二重円筒容器内における空気の磁気レイリー・ベナール対流”, 日本機械学会論文集 B 編, Vol. 77, No. 773 (2011), pp. 106 - 119.

(13) Bai, B., Yabe, A., Qi, J. and Wakayama, N.I., "Quantitative analysis of air caused by the magnetic-fluid coupling", $A I A A$ Journal, Vol. 37, No. 12, (1999), pp. 1538-1543.

(14) Tagawa, T., Shigemitsu, R. and Ozoe, H., "Magnetizing force modeled and numerically solved for natural convection of air in a cubic enclosure: effect of the direction of the magnetic field", International Journal of Heat and Mass Transfer, Vol. 45, (2002), pp. 267-277.

(15) Bednarz, P. T., Lei, C., Patterson, J. C. and Ozoe, H., "Effect of a transverse magnetic field on natural convection of a paramagnetic fluid in a cube", International Journal of Thermal Science, Vol. 48, (2009), pp. 26-33. 